\title{
FORESTRY IN FAO
}

\author{
By D. Roy Cameron
}

\section{Acting Corordinator Resources Development,}

Department of Reconstraction and Supply, Ottawa

I was very pleased indeed to accept the invitation of the President of the Society to tell you something of forestry functions and activities in the Food and Agriculture Organization of the United Nations. My task has been made easier by the fact that the background of the picture has been very capably set forth in the article appearing in the December, 1946, issue of The Forestry Chronicle entitled "Forestry and FAO", written by the immediate past President of the Society J. D. B. Harrison. He has explained how forestry came into $\mathrm{FAO}$, and the organization that has been set up to deal with it.

$\mathrm{FAO}$ is an international body and in forestry, as in other parts of its field, it deals primarily with the world picture. Sir John Boyd Orr, Director General of FAO, in his preface to the so-called "Stockholm report" (to which I will refer later) has given in sweeping strokes the broad outline of the forestry problem. From this I quote as follows:

"To state the world's forest problem in broad terms is not difficult. There is a shortage of wood, despite the fact that the world has more than enough forest soil to provide wood for the earth's peoples, even under an expanding economy.

"The remedy too is clear. The forests must be managed as perpetually renewable crops. Waste must be reduced. Legislation must be invoked and the forces of education mobilized to protect the forests from fire and destructive exploitation. Afforestation must be undertaken on a scale never before dreamed of, to create forest values in areas now barren and restore millions of hectares lost to agriculture. The two thousand million hectares of forests that still remain untouched must be converted into economic and social assets. The number of trained foresters must be increased many times.

"A comprehensive world forest policy must be directed toward a dual goal: First, sufficient forest areas to ensure the benefit of their protective influences, and second, a permanent and abundant supply of forest products. The rehabilitation of the world's forests is a huge task worthy of a world effort. It will take time, it will call for teamwork on an international scale; but success will mean richer, better lives to hundreds of millions. As part of the world-wide battle against human want to which FAO has pledged itself, the full use of the world's forests must play an indispensable and permanent role, for no effort to build up world agriculture can hope for success unless it builds up the forests of the world."

1 Paper presented at the 39 th annual meeting of the Canadian Soeiety of Forest Engineers, Vancouver, B.C., February 26-28, 1947. 
Forestry in FAO is divisible, like all Gaul, into three parts:

First-Policy recommendations approved by the annual FAO conferences based on the work of the conference committee on forestry and forest products.

Second-Recommendations to the Director General formulated by the Standing Adivsory Committee on Forestry and Forest Products.

Third-The Forestry and Forest Products Division of FAO, which has the duty and responsibility of translating policy into action.

Most of you have seen the forestry recommendations of the Quebec Conference. Few of you have yet had an opportunity to examine the report and recommendations of the Forestry Committee of the Copenhagen Conference, which were formally approved in the final plenary session of that conference. Likewise, the report of the Standing Advisory Committee, which was circulated as one of the documents made available to delegates at the Copenhagen Conference, has not yet been made generally available, nor has the Stockholm report which, to my mind, is the most important forestry publication extant.

It is my purpose to give you some insight into the workings of the two committees and to indicate the recommendations which they have made.

\section{The Conference Committee}

You should understand that under the FAO constitution each nation has only one vote. The responsibility for casting this vote is on the delegate from each nation. The delegate, however, in practice usually exercises this function personally only in plenary sessions of the conference or in the General Committee. Each national delegation includes a number of associate delegates, observers, etc., from whom the delegate nominates indi. viduals to represent him on the commissions, committees, sub-committees, etc., of the conference. In exercising this responsibility each person so nominated must voice the official views of his country, and not merely his own personal opinions. So far as Canada is concerned, the way this worked in practice was that each morning a private meeting of the national delegation was held, and any contentious points coming up for discussion in any conference committee were explained, and the representative authorized to take a certain stand. As a Canadian representative on the Forestry Committee both at Quebec and Copenhagen, I found this practice very effective and stimulating. It not only provided authoritative backing, but gave opportunity for examination of forestry problems with members of the Canadian delegation, who were thus lead to take an active interest in them. Naturally the operation worked also in reverse and gave the speaker some insight into agriculture nutrition and fisheries problems.

The committees of the conference are not restricted to one representative from each country, although only one vote can be cast. At Copenhagen I was fortunate in having as an associate Colonel Douglas Rowe, Canadian Government Timber Trade Commissioner in the United Kingdom. 
The attendance list for the Committee meetings at Copenhagen comprises 35 representatives of 18 countries, including two observers from Sweden and one from Finland. Lyle Watts, Chief of the United States Forest Service, was Chairman, and B. Dufay, Director General of Waters and Forests of France, was Rapporteur. Among other members were Professor $\mathrm{H}$. G. Champion, of the Imperial Forestry Institution, Oxford, and D. J. Rodger, Director General of Forestry of Australia: Naturally all the senior officers of the staff of the Forestry and Forest Products Division of FAO were also present.

The Forestry Committee at Copenhagen set up two sub-committees, one on forestry and one on forest products. These sub-committees each prepared a report, and these were then combined to form the final forestry report to the conference.

The discussions in the Forestry committee were influenced to a considerable degree by the main item on the conference agenda; namely, the Director General's proposal for a world food board. This proposal, which was backed in principle by the representatives of the great powers, included forest and fisheries products as coming under the jurisdiction of the proposed world food board. The recommendations to be made by the Forestry Committee were inevitably coloured by this over-riding fact. Parenthetically, you will remember that at the recent Washington meetings of the Preparatory Commission set up by the Copenhagen Conference, the United States reversed the stand taken by its delegates at Copenhagen. lows:

The major recommendations of the Forestry Committee were as fol-

1.

World Food Board

"The output of forest products based on the permanent growing capacity of now accessible forests is insufficient to meet world demand. There also exists the danger of possible future surpluses. This creates a situation essentially similar to the position in regard to food. It is therefore necessary and urgent that forest products be actively considered by the World Food Board as commodities requiring positive action. To ensure that world wood requirements receive adequate attention, it is recommended that countries nominating members to the World Food Board should give consideration to proper representation for forest products.

2.

World Wood Program

"In view of the urgency of the problems involved, and in order to prepare the necessary information for the work of the World Food Board, it is recommended that FAO's Forestry Division take all necessary steps without delay for the establishment of lumber and forest products balances with regard to Europe, North America, Asia, and the Southern Hemisphere for several years ahead. These regional bal. ances should then be co-ordinated and circulated among FAO member 
governments in order to permit discussion of a world forestry program based on these balances either at FAO's next annual conference or by the appropriate agencies concerned with the preparation or the functioning of the World Food Board.

3.

European Problem

"In view of the gravity of the reconstruction problem in devastated countries of Europe, it is recommended that the appropriate international authority call an urgent conference of European governments to consider immediate action to provide devastated countries with the help they need in order to overcome the present difficulties with regard to lumber supplies, especially as far as these supplies are essential for reconstruction work.

\section{National Committees and Regional Offices}

"In order to enable FAO's forestry organization to function effectively, it is considered indispensable-

(a) That there be created as quickly as possible within the framework of the National FAO Committee for each country a subcommittee for forestry and forest products with a secretary perm. anently assigned to it; and

(b) That the Forestry Division of FAO organize one central and three regional offices as soon as funds and personnel can be made available.

"The central office would at the same time serve a fourth region. The regions envisaged are (1) North America; (2) Europe, including Russia and the whole Mediterranean basin; (3) Latin America and Africa, with the exception of the Mediterranean basin; and (4) Asia, with Oceania. The possible creation of a fifth office for the Pacific Area may be considered at a later stage.

"The early development of the European center is considered by the Committee to be especially urgent. As far as possible, these officials should be at the same places as those which FAO may decide to maintain for its other work. Pending their actual installation, it is desirable that a special officer of the Forestry Division be assigned to each of these four regions.

5.

\section{Mission to Latin America}

"One of the first measures to alleviate the present wood shortage is the development of unexploited forest resources in Latin America, es. pecially of the great reserves of Parana pine. As soon as the consent of the interested governments can be obtained, a mission should be organized to investigate these resources and advise on their development. This mission should leave, if possible, before the end of this year and visit the most important forest regions of Latin America. It should endeavour to arouse the interest of Latin American people in the orderly development of their enormous forest wealth." 
There were 21 other recommendations, the most important of which dealt with the preparation of a census of the world's forests, measures to be taken to increase the number of professional foresters, reforestation, seed and plant certification, pulp consumption levels, wood chemistry, proposed statistical conference, and a Third World Forestry Conference to be held in Europe, possibly Stockholm, in 1948. With minor changes the Committee approved the Stockholm report for presentation to the conference.

The Conference sessions at Copenhagen were broken by two field trips. One of these was to inspect Crown forests largely producing soft woods. mostly European spruce. The other trip provided an opportunity to see privately managed woodlands, (beech and oak) under very intensive cultural methods. Both the costs and the returns of Danish forestry are remarkable.

\section{Standing Advisory Committee on Forestry}

This Committee was set up by the Director General to advise him on forestry matters. The members, while coming from different countries, are specifically enjoined to divorce themselves from all national considerations, and to tender advice solely on the basis of the best policy and programmes to meet world problems. The Committee which met at Oslo prior to the Copenhagen conference comprised members representing the following countries:

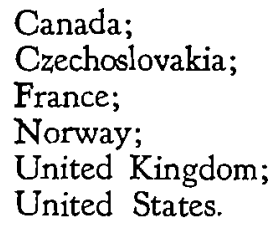

Senior members of the FAO staff were also in attendance.

The purposes of the meetings were to receive the report of the Director of Forestry and Forest Products on the activities of this division, and his proposals for further work; to recommend an agenda for the Forestry Committee of the Copenhagen conference, and to review and approve the Stockholm report. Of the Committee's recommendations several were included in the major recommendations of the Forestry Committee, which I have quoted above. The most important were: the need for a conference of European governments re lumber supplies, the setting up of regional offices and national committees, and the mission to Latin America. The proposal for a World Forestry Congress in 1948 was also recommended. In addition, the Committee recommended to the Director General that it be authorized to set up sub-committees as follows:

1. Education;

2. Forest Management;

3. Forest Research;

4. Unexploited Forests;

5. Statistics of Forest Products; 


\section{Technology of Mechanical Forest Products; \\ 7. Technology of Chemical Forest Products.}

It was suggested that the Subcommittee of Forest Research should be asked to examine the work of the union of Forest Research staffs and make recommendations as to co-operation or amalgamation.

Naturally, considerable attention was devoted to the critical wood supply situation in Europe. Returns to the Forestry Division of FAO showed that, on the whole, direct war damage suffered by European forests is smaller than had been feared. There are, of course, exceptions to this, notably Great Britain, Greece, and Poland. Aside from these countries, it is probable that in continental Europe not more than the increment of the next two to five years has been cut. In Northern Europe growing stocks remain practically unimpaired. However, even before the war, and despite relatively intensive management over a long term of years, there had been over'cutting in Europe, particularly of saw timber. This was reflected in a continuing reduction in the average diameter of saw logs. The only major nations in which a satisfactory balance between growth and drain had been fully maintained were the Scandinavian countries, France, and pre-Nazi Germany. The gradual degradation and depletion of forests in other European countries had been causing serious concern even before the war.

Estimates made in the Stockholm report, presented to the Committee at Oslo, indicated that 1946 fellings over Europe as a whole would exceed annual growth by 21 per cent. Despite the substantial over-cutting a large deficit remains, particularly in lumber. What is worse, future European requirements will rise as soon as transport and other difficulties have been overcome.

This situation poses a serious threat to European forests, a threat that will be aggravated by shortages of dollars and other currencies. Unless remedial measures are taken, excessive cuttings will increase, not only to meet domestic needs but as a necessary means of securing foreign exchange required for the security of the national economy of many nations.

To meet the short-term lumber emergency the Committee asked the Director General to request member nations to confine construction during 1946.47, as much as possible, to essential housing and related urgent needs; also to request the four occupying powers in Central Europe to estimate reparations in the form of timber that might be taken from Germany. The Committee felt that a sharp reduction could be made in the growing stock of German forests, either by shortening the rotation or by heavy thinnnings in closelysstocked areas. Furthermore, the attention of the U.S.A. should be called to the need for dollar credits to European export countries, to help retain European wood for European use.

For the long-term picture the Committee saw the need for a new assessment of the European forestry situation. Border changes demand new estimates of prospective wood consumption and import requirements to determine to what extent Europe's deficit countries can be served from European sources, and how much non-European wood will be needed. All European 
nations must be encouraged to increase wood yields and to this end full advantage must be taken of expanded research and technological develop. ment.

As regards the world situation, the Committee advised the Director General that FAO should encourage member governments to consider the following measures:

"(1) Legislation subjecting all forests in use to compulsory management based on the maintenance of a permanent balance between annual drain and annual growth;

(2) The introduction of advanced silvicultural methods capable of increasing annual yield per hectare;

(3) A program for the orderly development and management of the world's virgin forests;

(4) Systematic afforestation of all denuded soils suited for forest growth;

(5) The introduction of utilization methods and establishment of integrated forest industries to make full use of the forest crop;

(6) Development of wood consumption patterns providing the world's peoples with sufficient forest products for adequate living standards;

(7) Stimulation and encouragement of silvicultural and wood utilization research;

(8) Development of educational facilities and adoption of training programs to provide an adequate supply of professional foresters and wood engineers."

As regards $\mathrm{FAO}$ activities the need was stressed of a world conference on Forestry statistics, to establish clear relations and conversion factors between national statistics and FAO's standard terms and units. It was recommended to the Director General that the division of Forestry and Forest Products should take

"immediate steps to establish essential data and balance sheets dealing with the world's forest resources and major forest products. These efforts may be coupled with the preparation of a world forest census, and result in the publication of a world handbook containing standard information with regard to the forests and forest products of all nations."

During the course of the meetings at Oslo a field trip, arranged by the Government of Norway, provided opportunity for inspection of some of the best stands of privately owned timber (spruce and pine) and an understanding of Norwegian forestry practice.

The Stockholm report gave the Committee some interesting data on trade and consumption of forest products. The world's annual forest crop is estimated at from one thousand to twelve hundred million tons. It is out-ranked only by coal (thirteen-hundred million tons), and represents several times the gross tonnage of all the world's minerals. Wood serves a greater diversity of purposes than any other material. 
By quantity, fuel is still the largest single use of wood and accounts for 53 per cent of the annual crop. Lumber comprises 30 per cent of the annual wood cut, and pulpwood about 10 per cent. However, there has been a steady rise in the absolute and relative importance of pulpwood requirements. Even in 1937 Swedish pulp industries converted 10 per cent more round wood than the lumber industry. From the general economic point of view, pulp appears to be the best use for the forest crop. There will always, however, be a steady demand for lumber as an inexpensive build. ing material with outstanding technical qualities. The answer lies in inte. gration confining pulp production, so far as possible, to material not well suited for lumber.

The total value of all primary forest products is estimated at around seven billion dollars. This is exceeded only by milk in production value, and is far ahead of all other foods and raw materials.

The figures above quoted indicate the importance of forests and forestry in the world economy. For Canada, where over half the land area within provincial boundaries is suited primarily for the production of wood crops, surely there is a lesson in these figures, not only for forestry but for every citizen. In this country forestry is more than an industrial problem to en. sure raw materials. It is a land-use problem of first importance in the Canadian economy.

It seems to me that our main task as a Society should be to drive home the point that Canada's full destiny can only be reached as we make full, wise, and efficient use of the productive capacity of Canadian forest lands. 